\title{
Löfgren Sendromunda Kas-iskelet Sistemi Bulgularının Değerlendirildiği Klinik Araştırma
}

\author{
Koray AYAR, Selime ERMURAT \\ Sağlık Bilimleri Üniversitesi Bursa Yüksek İhtisas Eğitim ve Araştırma Hastanesi, İç Hastalıkları Anabilim Dalı, \\ Romatoloji Bölümü, Bursa.
}

\begin{abstract}
ÖZET
Biz bu çalışmada Löfgren sendromu ile takipli olan hastaların başlangıç eklem bulgularını ve seyrini, eklem bulgularına eşlik eden bulguları tespit etmeyi, kronik ve akut artrit ile seyreden olguların eklem ve laboratuvar bulguları ile kullandıkları ilaçları karşılaştırarak hangi değişkenlerin kronikleşmeyi etkilemiş olabileceğini araştırmayı amaçladık. Çalışmada 3071 hastanın dosyası retrospektif olarak incelenmiş olup 12 Löfgren sendromlu hasta çalışmaya dahil edilmiştir. Hastaların başlangıç klinik ve laboratuvar bulguları hasta dosyalarından, başlangıç görüntüleme tetkikleri "PACS" sisteminden, kas iskelet sistemi bulguları da telefonla veya yüz yüze görüşülerek elde edilmiştir. Katılımcılar akut artrit ( $<6$ hafta) ve kronik artrit ( $\geq 6$ hafta) olarak 2 gruba ayrilarak eklem tutulum paternleri ve laboratuvar bulguları gruplar arasında karşılaştırılmıştır. Kullanılan ilaçların sıklığına göre eklem tutulum paternleri de incelenmiştir. Katılımcıların başlangıç klinik bulguları sıklık sırasına göre artrit $(\% 58,3)$ eritema nodozum $(\% 58,3)$, göğ̈̈s ağrısı $(\% 16,6)$, bel ağrısı $(\% 8,4)$, nefes darlığı $(\% 8,4)$ ve öksürüktür $(\% 8,4)$. Ayak bileği ödemi, akut artrit ve oligoartrit sıklıkları sirasıyla \%75,0, \%58,3 ve \%75,0'dır. El bileği ve proksimal interfalangial eklemlerin tutulumlarının sıklıkları kronik artrit seyri olanlarda sırasıyla $\% 40$ ve $\% 20$ iken akut artrit seyri olanlarda sırasıyla $\% 14,7$ ve $\% 0$ oranında tespit edilmiştir. Sülfasalazin, hidroksiklorokin ve kolşisin kullananlarda kronik artrit seyri sırasıyla \%20, \%75 ve \%100 oranındaydı. Löfgren sendromunda el bileği, proksimal interfalangial eklem ve dirsek tutulumu kronik artrit seyrinde daha sıktır, anjiyotensin dönüştürücü enzim akut artritte daha yüksek görülme eğilimindedir; bunun dışında hastalığın seyrinde ayırt ettirici olabilecek karakteristik klinik ve laboratuvar özellik yoktur. Sülfasalazin gibi potensi yüksek hastalığı modifiye edici ilaçlar hastalığın eklem bulgularının daha kısa sürede kontrol altına alınmasında etkili olabilirler.
\end{abstract}

Anahtar Kelimeler: Eritema nodozum. Löfgren sendromu. Sarkoidoz.

Clinical Research Evaluating Musculoskeletal Findings in Löfgren's Syndrome

\begin{abstract}
In this study, we aimed to determine the initial joint findings in Löfgren's syndrome and investigate which variables might have affected chronicity in patients with the drugs they used. Charts of 3071 patients were analyzed retrospectively and 12 patients were included in the study. The initial clinical and laboratory findings of the patients were obtained from the patients charts, the initial imaging with Löfgren syndrome examinations were obtained from the PACS system, and the musculoskeletal system findings were obtained by telephone or faceto-face interview. Participants were divided into 2 groups as acute ( $<6$ weeks) and chronic arthritis ( 6 weeks) and joint patterns and laboratory findings were compared between groups. Joint patterns were also analyzed according to the frequency of the drugs used. Initial clinical findings were arthritis (58.3\%), the erythema nodosum (58.3\%), chest pain (16.6\%), low back pain (8.4\%), shortness of breath (8.4\%) and cough (8.4\%). The frequencies of ankle edema, acute arthritis and oligoarthritis were $75.0 \%$, $58.3 \%$ and $75.0 \%$, respectively. While the frequency of and proximal interphalangial joint involvement was $40 \%$ and $20 \%$ in chronic arthritis, it was $14.7 \%$ and $0 \%$, respectively, in acute arthritis. The course of chronic arthritis in sulfasalazine, hydroxychloroquine and colchicine users was $20 \%$, $75 \%$ and $100 \%$, respectively. Wrist, proximal interphalangial joint and elbow involvement are more common in chronic arthritis, angiotensin converting enzyme tends to be higher in acute arthritis; apart from this, there are no characteristic features that can be distinguished in the course of the disease. High potency disease-modifying drugs such as sulfasalazine may be effective in controlling joint symptoms of the disease in a shorter time.
\end{abstract}

Key Words: Erythema nodosum. Löfgren's syndrome. Sarcoidosis.

Geliş Tarihi: 26.Ağustos.2020

Kabul Tarihi: 01.Ekim.2020

Dr. Koray AYAR

Sağlık Bilimleri Üniversitesi

Bursa Yüksek İhtisas Eğitim ve Araştırma Hastanesi,

İç Hastalıkları Anabilim Dalı,

Romatoloji Bölümü, Bursa.

Tel: 05325618450

E-posta: ayarkoray@hotmail.com

Yazarların ORCID ID Bilgisi:

Koray AYAR: 0000-0002-8798-4828

Selime ERMURAT: 0000-0001-9945-8940
Sarkoidoz etyolojisi bilinmeyen, histopatolojik olarak non-kazeifiye granulomatoz lezyonlarla karakterli, multisistemik bir hastalıktır. Bilateral hiler lenfadenopati, eritema nodozum, akut poliartrit/poliartralji ve ateş birlikteliğiyle seyreden akut sarkoidoz tablosu "Löfgren sendromu" olarak bilinir ve sarkoidoz olgularını \%5-10'luk bir kısmında görülen nadir bir klinik durumdur ${ }^{1,2}$. Löfgren sendromunun tüm klinik bulgularının birlikte var olması sarkoidoz tanısı için \%95 özgüllüğe sahip olduğundan biyopsi ile tanı konmasına gerek kalmaz ${ }^{3}$. Löfgren sendromunda şikayetlerin 
hızlı bir başlangıç göstermesi ve kas-iskelet sistemi bulgularının ön planda olması nedeniyle bu hastaların ilk değerlendirilmesi genellikle romatoloji polikliniklerinde yapılmaktadır. Löfgren sendromunda tutulan eklem paterni ve eşlik eden diğer klinik bulgular ile ilgili sınırlı bilgi olsa da büyük oranda ayak bileği eklemi tutulumu ile birlikte diğer büyük eklem tutulumları da görülebilmektedir ${ }^{1}$. Bu nedenle benzer eklem tutulumu olan diğer romatolojik hastalıklar ile ayırıcı tanısı bazen güç olabilmektedir. $\mathrm{Bu}$ durum nedeniyle Löfgren sendromundaki eklem tutulum paterni ve eşlik eden diğer kas-iskelet sistemi bulguları hakkında ayrıntılı bilgiye sahip olmak klinisyenler için önemli olmaktadır. Löfgren sendromunda kronikten ziyade akut eklem inflamasyonu görülmekte ve inflamasyon çoğunlukla kendini sınırlamaktadır, ancak bazı kişilerde kronik seyirde görülebilmektedir. Literatürde eklem semptomlarının süresi ile hastalığın hangi klinik ve laboratuvar bulgularının ilişkili olduğu, hangi tedavilerin kronikleşmeyi azalttığı ile ilgili de yeterince bilgi bulunmamaktadır.

Biz bu çalışmada kliniğimizde Löfgren sendromu ile takipli olan hastaların başlangıç eklem bulgularını ve seyrini, eklem bulgularına eşlik eden diğer spesifik klinik ve laboratuvar bulgularını tespit etmeyi; ayrıca kronik ve akut artrit ile seyreden olguların eklem bulgularını, laboratuvar bulgularını ve kullandıkları ilaçları karşılaştırarak hangi değişkenlerin kronikleşmeyi etkilemiş olabileceğini araştırmayı amaçladık.

\section{Gereç ve Yöntem}

Çalıșmanın etik kurul onayı Sağlık Bilimleri Üniversitesi Bursa Yüksek İhtisas Eğitim ve Araştırma Hastanesi Klinik Araştırmalar Etik Kurulu'ndan alınmıştır (04.03.2020 tarih ve 2011-KAEK-25 2020/03-18 nolu karar).

\section{Çalışma Dizaynı ve Hasta Seçimi}

Çalışmamız retrospektif bir kohort çalışmasıdır. Hastanemiz Romatoloji kliniğinde takipli olan hastaların dosyaları "sarkoidoz", "löfgren sendromu", "eritema nodozum" tanı kodları ile tarandı. Çalışmaya dahil edilme kriterleri; 18 yaş üstünde olmak, eritema nodozum, hiler lenfadenomegali (Lam), gezici poliartrit bulguları ile birlikte lenf nodu biyopsisinde nonkazeifiye granülomların tespit edilmiş olması veya biyopsi yapılmamış olan hastalarda eritema nodozum, Lam, gezici poliartrit ve ateş bulgularının hepsinin birden var olmasıdır. Çalışmanın dışlama kriterleri; tanı konduktan sonra dosyadaki bilgilerden klinik takipleri hakkında yeterli bilgi alınamaması veya telefonla ulaşılamamasıdır.

\section{Verilerin Toplanmast}

Hastaların dosyalarından hastaların demografik verileri ve laboratuvar tetkikleri incelendi, PACS sisteminden geriye dönük hastaların tanı anında çekilen arka- ön akciğer röntgenleri ve Akciğer tomografi görüntüleri incelendi. Fotoğraf arşivinden tanı anında ve takiplerdeki cilt bulguları ile ilgili fotoğrafları olanlar tespit edildi. Hastalık başlangıç bulguları, eklem tutulum paternleri, eşlik eden klinik durumlar ve kasiskelet sistemi bulgularının iyileşmesi ile ilgili bilgiler katılımcılar telefon ile aranarak veya yüz yüze poliklinikte görüşülerek elde edildi.

\section{Alt Grupların Değerlendirilmesi}

Eklem tutulumu 6 haftadan kısa sürenler akut artrit, eklem tutulumu 6 haftadan uzun sürenler kronik artrit grubuna dahil edildi. Akut ve kronik artritli hastalar yaş, cinsiyet, hastalık süresi, başlangıç laboratuvar bulguları, eklem tutulum paterni, hangi eklemlerin tutulduğu, semptom düzelme süreleri ve tedavi sürelerine göre kıyaslandı. Ayrıca hastalar kullandıkları ilaçlara göre akut ya da kronik seyirli olarak gruplandırıldı. Hangi ilacı kullananlarda akut veya kronik artrit görüldügüü araştırıldı.

\section{İstatistiksel Analiz}

İstatistiksel analizde SPSS paket programının 20. Sürümü kullanıldı. Betimleyici değerler yüzdelik, ortalama, standart sapma, ortanca, minimum ve maksimum değerleri ile birlikte verildi. Verilerin normal dağılıma uyup uymadığı "Shapiro-Wilks" testiyle değerlendirildi. Normal dağılıma uyan değişkenler için bağımsız iki grubun karşılaştırılmasında t-testi, normal dağılıma uymayan değişkenler için bağımsız iki grubun karşılaştırılmasında "Mann Whitney-U" testi kullanıld1. Anlamlılık düzeyi $\mathrm{p} \leq 0,05$ olarak kabul edildi.

\section{Bulgular}

Romatolojik hastalık tanıs1 ile kayıtlı 3071 hastanın dosyasının tanı kodları ile taranması sonucu 33 sarkoidoz hasta dosyasına ulaşıldı. Tüm kriterleri karşılayan toplam 12 Löfgren sendromlu hasta çalışmaya dahil edildi. Hastaların 1'i hariç hepsine tanı amaçlı biyopsi yapıldığı, biyopsi sonuçlarında non-kazeifiye granülomatöz reaksiyon tespit edildiği ve sarkoidoz ile uyumlu olarak raporlandığı tespit edildi. Biyopsi yapılmış olan hastaların üçüne mediastinal eksizyonel biyopsi, 8'ine endobronşial ultrasonografi eşliğinde hiler lenf nodu biyopsisi yapılmıştı. Biyopsi yapılmadan tanı konmuş olan hastanın eritema nodozum, hiler Lam, gezici poliartrit ve ateş bulgularının hepsine sahip olduğu diğer 11 hastanın ise eritema nodozum, hiler Lam ve gezici poliartrit bulgularının hepsine sahip olduğu tespit edildi.

\section{Olguların Başlangıç Verileri}

Çalışmaya dahil edilen katılımcıların demografik verileri, klinik ve laboratuvar bulguları ve aldıkları tedaviler Tablo-I'de gösterilmiştir. Hastaların yaş ortalaması 42,42 $\pm 9,6$ idi; 10'u $(\% 83,3)$ kadın, 2'si $(\% 16,6)$ erkekti. 


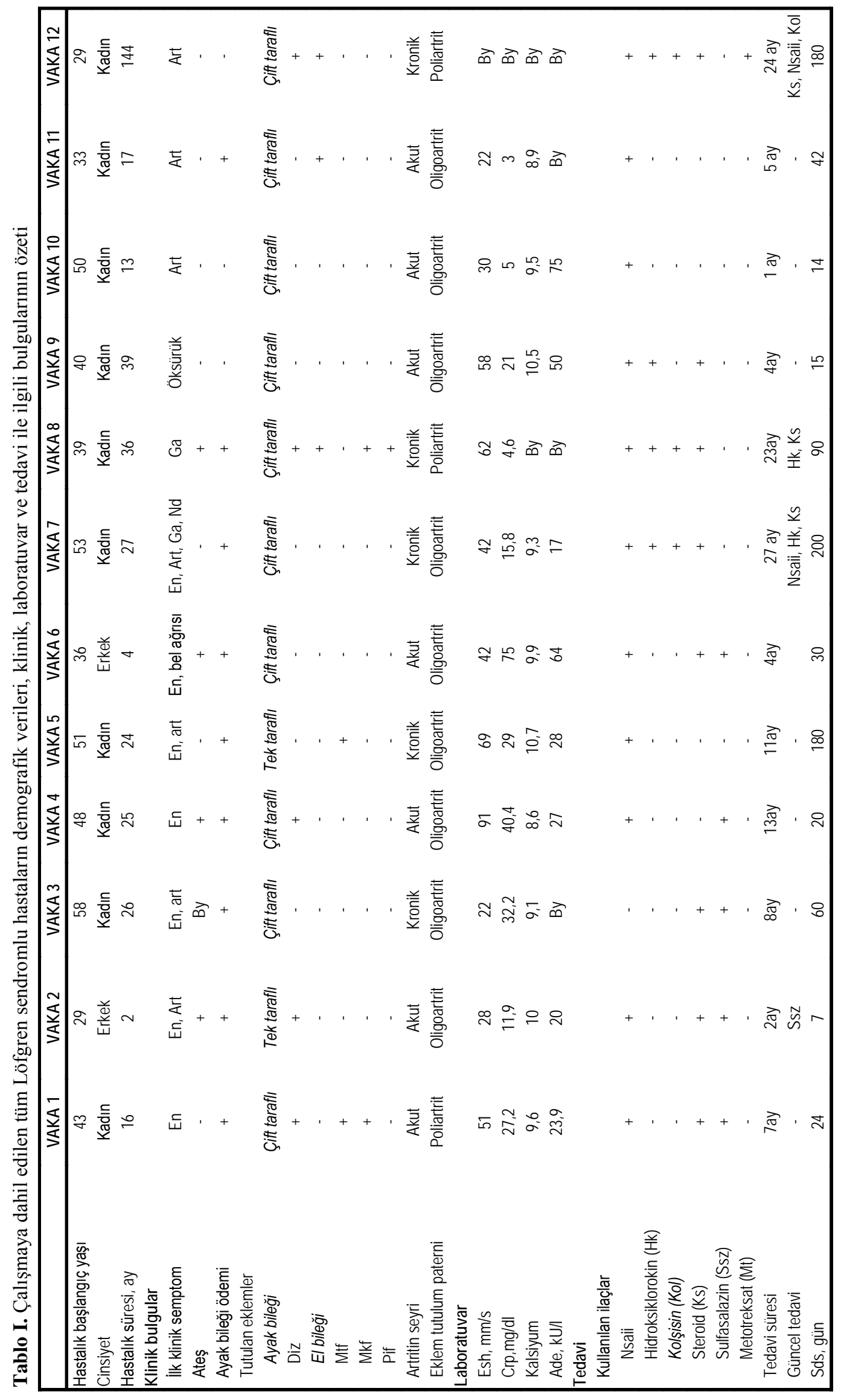


Klinik bulgular: Olguların klinik bulguları değerlendirildiğinde en sık görülen başlangıç klinik bulguları değerlendi \%58,3 sıklığında eritema nodozum ve artrit olduğu, diğer başlangıç klinik bulgularının ise \%16,6 sıklığında görülen göğüs ağrısı ve \%8,3 sıklıklarında görülen bel ağrısı, nefes darlığı ve öksürük olduğu tespit edildi. Eşlik eden klinik bulgular değerlendirildiğinde olguların \%75'inde ayak bileği ödemi ve $\% 33,3$ 'ünde ateş mevcuttu. Ayak bileği ödeminin ultrasonografi görüntüleri Şekil-1'de gösterilmiştir. Tutulan eklemler değerlendirildiğinde hastaların 7 'sinde $(\% 58,3)$ eklem tutulumunun akut, 5'inde ise kronik $(\% 41,6)$ seyirli olduğu tespit edildi. Katılımc1ların 9'unda (\%75) artritin seyri oligoartrit, 3'ünde (\%25) poliartrit şeklinde idi. Tutulan eklemler sıklık sırasına göre; ayak bileği $(\% 100)$, diz $(\% 41,6)$, el bileği (\%25), metakarpofalangeal eklem (MKF) (\%16,6), metatarsofalangeal eklem (MTF) $(\% 16,6)$, proksimal interfalengeal eklem (PIF) $(\% 8,3)$, kalça $(\% 8,3)$ ve dirsek eklemi $(\% 8,3)$ şeklinde idi. Katılımcılardan bazılarının hastalığın başlangıç döneminde ve takiplerdeki eklem ve cilt bulgularının ve başlangıç mediastinal Lenf nodlarının görüntüleri Şekil-2'de gösterilmiştir. Alt ekstremitede görülen eklem tutulum paterninin (artrit+ödem+eritema nodozum) aynısı üst ekstremite tutulumu olanlarda da benzer şekildeydi (Şekil-3).

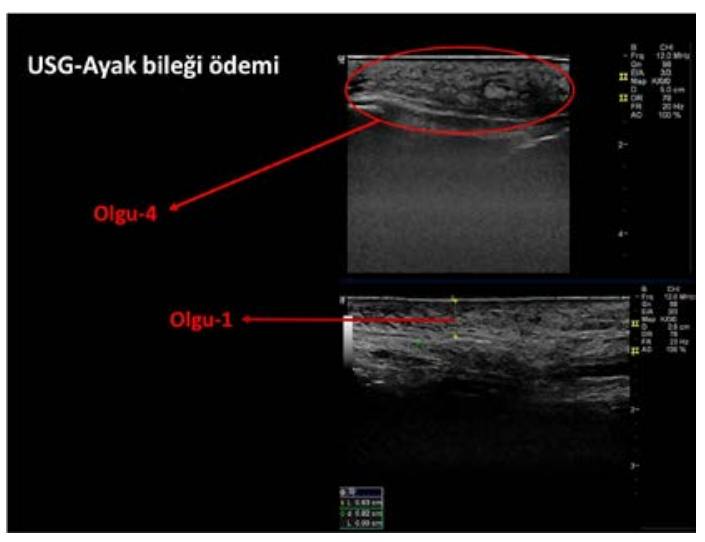

Şekil 1:

Ayak bileği ödeminin ultrasonografik görünümü

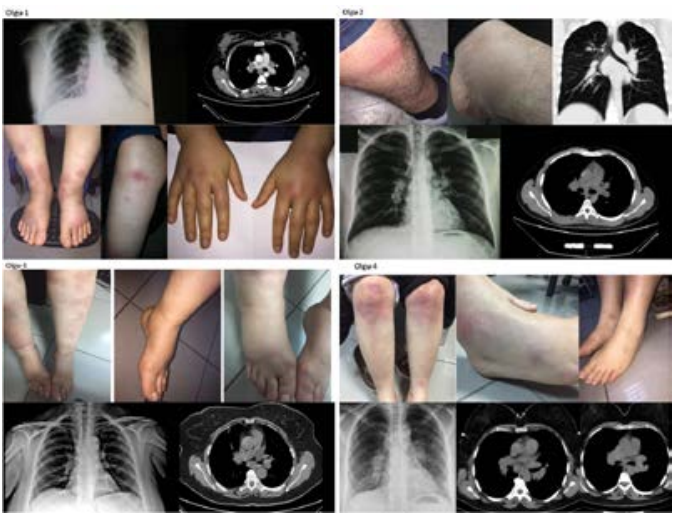

Shekil 2:

Hastalı̆̆ın başlangıç döneminde ve takiplerdeki eklem ve cilt bulgularının ve başlangıç mediastinal Lam 'ların görüntüleri

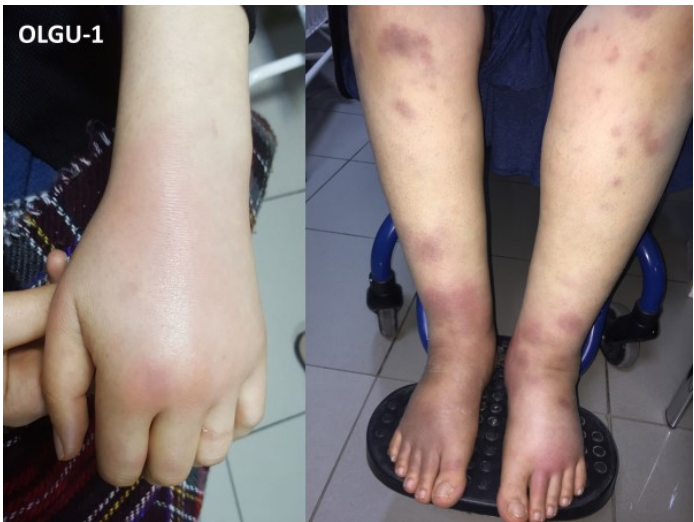

Şekil 3:

Löfgren sendromlu bir olguda eşzamanlı olarak görülen alt ve üst ekstremitedeki patolojilerin (eritema nodozum, ödem, artrit) görüntüleri

Laboratuvar ve tedavi ile ilgili bulgular: Tanı esnasında bakılan eritrosit sedimentasyon hızı (Esh) düzeyi 46,9 $\pm 21,8 \mathrm{~mm} / \mathrm{saat}$, C-reaktif protein (Crp) düzeyi 26,2 $\pm 20,7 \mathrm{mg} / \mathrm{dl}$, kalsiyum 9,6 $\pm 0,67 \mathrm{mg} / \mathrm{dl}$, anjiyotensin dönüştürücü enzim (Ade) $38,1 \pm 21,9 \mathrm{kU} / 1$ idi. Hastaların 9'unda (\%75) ESH, 8'inde (\%66) Crp, 5'inde $(\% 41,6)$ kalsiyum, 3’ünde (\%25) Ade düzeyi referans değerlerin üzerinde idi. Bir hasta haricindeki tüm hastalarda (\%91,7) non-steroidal anti inflamatuvar ilaç (Nsaii) kullanılmıştı. Hastaların 4'ünde $(\% 33,3)$ hidroksiklorokin $(\mathrm{Hk}), 3$ 'ünde $(\% 25)$ kolşisin, 8 'inde $(\% 66,6)$ kortikosteroid (Ks), 5'inde $(\% 41,7)$ sulfasalazin (Ssz), 1'inde $(\% 8,3)$ metotreksat (Mt) kullanılmıştı. Hastaların son takiplerinde 5'i $(\% 41,6)$ halen tedavi almakta iken, 7'si $(\% 58,3)$ ilaçsız takip edilmekteydi. Semptomların ortalama düzelme süresi 37,5 gündü.

Akut ve Kronik Artrit Gruplarında Bulguların Karşılaştırılması

Eklem tutulum paternine göre sinıflandırılan hastaların demografik verileri, laboratuvar sonuçları ve eklem bulgularının karşılaştırılması Tablo-II'de gösterilmektedir. Akut artrit grubunda 7, kronik artrit grubunda 5 katılımcı mevcuttu. Akut ve kronik seyirli Löfgren sendromlu hastalar arasında yaş ve cinsiyet açısından fark saptanmadı. Hastalık süresi akut artrit grubunda 16,0 (2-29) ay iken, kronik artrit grubunda 27,0 (24144) ay olup gruplar arasındaki fark istatistiksel olarak anlamlı $(\mathrm{p}=0,048)$ bulundu. Tanı anı Esh, Crp, kalsiyum ve Ade düzeylerini içeren laboratuvar verileri gruplar arasında farklı değildi. Hastalarda tutulan eklemler değerlendirildiğinde akut artrit ve kronik artrit grupları arasında eklem tutulum sıklıkları istatistiksel olarak farklı değildi, ancak kronik artrit grubunda 5 hastanın 1 'inde (\%20) Pif, yine 5 hastanın 1'inde (\%20) dirsekte, 2 'sinde (\%40) el bileğinde artrit mevcutken, akut artrit grubunda hiçbir hastada PIF, dirsek tutulumu görülmedi ve sadece 1 hastada el bileği $(\% 14,2)$ artriti tespit edildi. 


\section{Löfgren Sendromunda Kas-iskelet Sistemi Bulguları}

Tedavide Kullanılan İlaca Göre Eklem Tutulum Paternlerinin Karşılaştırılması

Tedavide hangi ilacı kullandıklarına göre sınıflandırılan hastaların eklem tutulum paternlerinin karşılaşt1rılması Tablo-III'te özetlenmektedir. Katılımcıların 5 tanesinde Ssz kullanılmıştı, bunların 4 tanesinde (\%80) akut artrit 1 tanesinde (\%20) kronik artrit seyri tespit edildi ( $p=0,293)$. Hk katılımcıların 4'ünde kullanılmıştı ve bu 4 hastanın 3 tanesinde kronik artrit (\%75) 1 tanesinde ise akut artrit seyri (\%25) tespit edildi ( $\mathrm{p}=0,222)$. Akut artrit seyirli hastaların hiçbirinde kolşisin kullanımı tespit edilmezken, kolşisin kullanımı olan 3 hastada kronik artrit seyri olduğu görüldü $(p=0,045)$. Bunların dışında diğer ilaçların kullanım sıklıkları akut ve kronik seyirli artrit gruplarına birbirine yakın bulundu.

Tablo II. Artrit seyrine göre gruplandırılan Löfgren sendromlu hastaların demografik verilerinin, laboratuvar ve eklem bulgularının karşılaștırılması

\begin{tabular}{|c|c|c|c|}
\hline & $\begin{array}{l}\text { Akut artrit } \\
\quad(n=7)\end{array}$ & $\begin{array}{l}\text { Kronik artrit } \\
\qquad(n=5)\end{array}$ & $\mathrm{p}$ \\
\hline Yaş, yıl, ortalama \pm sd & $39,8 \pm 7,7$ & $46 \pm 11,8$ & 0,255 \\
\hline Kadın,n (\%) & $5(71,4)$ & $5(100)$ & 0,470 \\
\hline $\begin{array}{l}\text { Hastalık süresi, ay, ortanca } \\
\text { (min-maks) }\end{array}$ & $16,0(2-39)$ & $27,0(24-144)$ & 0,048 \\
\hline \multicolumn{4}{|l|}{$\begin{array}{l}\text { Tanı anında lab, ortanca } \\
\text { (min-maks) }\end{array}$} \\
\hline Esh, mm/saat & $42,0(22-91)$ & $52,0(21-69)$ & 0,788 \\
\hline Crp, mg/dl & $24,1(5,0-75,0)$ & $22,4(4,6-32,2)$ & 0,762 \\
\hline Ade, kU/l, ortalama $\pm s d$ & $43,3 \pm 23,1$ & $22,5 \pm 7,7$ & 0,108 \\
\hline Ateş, n (\%) & $3(42,8)$ & $1(20)$ & 0,853 \\
\hline Ayak bileği ödemi, n (\%) & $5(71,4)$ & $4(80)$ & 0,746 \\
\hline \multicolumn{4}{|l|}{ Eklem tutulumu, $n$ (\%) } \\
\hline Ayak bileği & $7(100)$ & $5(100)$ & 1,000 \\
\hline Tek taraflı & $1(14,3)$ & $1(14,3)$ & 1,000 \\
\hline Çift taraflı & $6(85,7)$ & $4(80,0)$ & 1,000 \\
\hline Diz & $3(42,9)$ & $2(40,0)$ & 1,000 \\
\hline Mtf & $1(14,3)$ & $1(20,0)$ & 1,000 \\
\hline El bileği & $1(14,7)$ & $2(40,0)$ & 0,332 \\
\hline Pif & $0(0)$ & $1(20,0)$ & 0,417 \\
\hline Mkf & $1(14,3)$ & $1(20,0)$ & 1,000 \\
\hline Kalça & $1(14,3)$ & $0(0)$ & 1,000 \\
\hline Dirsek & $0(0)$ & $1(20,0)$ & 0,417 \\
\hline Oligoartrit/Poliartrit, $n$ & $6 / 1$ & $3 / 2$ & 0,523 \\
\hline Semptom düzelme süresi, gün & $21,7 \pm 11,6$ & $142,0 \pm 62,6$ & 0,012 \\
\hline $\begin{array}{l}\text { Tedavi süresi, ay, ortanca (min- } \\
\text { maks) }\end{array}$ & $4,0(1-13)$ & $23,0(8-27)$ & 0.010 \\
\hline
\end{tabular}

sd: standart deviasyon, min: minimum, maks: maksimum, lab: laboratuvar, Esh: eritrosit sedimantasyon hızı, Crp: Creaktif protein, Ade: anjiotensin dönüştürücü enzim, Mtf: metatarsofalangial eklem, Pif: proksimal interfalanggial eklem, Mkf: metakarpofalangial eklem
Tablo III. Löfgren sendromlu hastaların kullandıkları ilaçlara göre eklem tutulumunun seyri

\begin{tabular}{|lcccccc|}
\hline & $\begin{array}{c}\text { Ssz } \\
(n=5)\end{array}$ & $\begin{array}{c}\text { Hk } \\
(n=4)\end{array}$ & $\begin{array}{c}\text { Mt } \\
(n=1)\end{array}$ & $\begin{array}{c}\text { Ks } \\
(n=8)\end{array}$ & $\begin{array}{c}\text { Kol } \\
(n=3)\end{array}$ & $\begin{array}{c}\text { Nsaii } \\
(n=11)\end{array}$ \\
\hline Etp (\%) & & & & & & \\
Akut artrit & $4(80,0)$ & $1(25,0)$ & $0(0)$ & $4(50)$ & $0(0)$ & $7(63,6)$ \\
Kronik artrit & $1(20,0)$ & $3(75,0)$ & $1(100)$ & $4(50)$ & $3(100)$ & $4(36,4)$ \\
P değeri & 0,293 & 0,222 & 0,417 & 1,000 & 0,045 & 0,417 \\
\hline
\end{tabular}

Etp: eklem tutulum paterni, Ssz: sülfasalazin, Hk: hidroksiklorokin, Mt: metotreksat, Ks: kortikosteroit, Kol: kolşisin, Nsaii: non-steroid olmayan anti-inflamatuvar ilaç

\section{Tartışma ve Sonuç}

$\mathrm{Bu}$ çalışma kohortundaki hastaların kas-iskelet sistemi patolojileri değerlendirildiğinde hastalarda en çok görülen eklem patolojisinin bilateral ayak bileği artriti olduğu, hastaların büyük bir çoğunluğunda ayak bileği artritine ayak bileği ödeminin de eşlik ettiği, eklem tutulum paterninin de daha çok akut ve oligoartrtiküler olduğu ve hastaların büyük bir bölümünde başlangıç akut faz reaktanlarının yüksek olduğu görülmüştür. 6 haftadan kısa ve uzun süren eklem tutulumu olan hastalar karşılaştırıldığında ise istatistiksel olarak anlamlı olmasa da el bileği, dirsek ve Pif eklem tutulumlarının kronik artrit grubunda daha sık görüldüğü, Ade düzeylerinin yine istatistiksel olarak anlamlı olmasa da akut artrit grubunda daha yüksek olma eğiliminde olduğu, diğer başlangıç laboratuvar bulgularının ve eklem tutulum paternlerinin birbirine benzer olduğu görüldü. Kullanılan ilaçlara göre akut ve kronik eklem tutulum sıklıkları karşılaştırıldığında ise yine istatistiksel olarak anlamlı olmasa da Ssz kullananlarda eklem bulgularının daha kısa, kolşisin ve Hk kullananlarda ise eklem bulgularının daha uzun sürme eğiliminde olduğu tespit edilmiştir. Literatürde Löfgren sendromunun eklem tutulum paterni ile ilgili sınırlı veri olsa da yapılan çalışmalardaki verilere göre olgulardaki eklem tutulumu çoğunlukla oligoartriküler seyreder ${ }^{4}$. Hem akut hem kronik grupta en sik tutulan eklem ayak bileğidir ( $>\% 90)$ ve bunu sıklık sırasına göre diz, dirsek, el bileği gibi diğer büyük eklemlerin tutulumu takip eder, tutulum paterni ise siklıkla simetriktir $^{5}$. İki aydan kısa süreli semptomu olan akut artrit hastalarının dahil edildiği prospektif bir kohort çalışmasında; 40 yaşından önce başlayan simetrik ayak bileği artriti sarkoid artrit tanısı için \%85 sensitivite ve \%99 spesifiteye sahiptir ${ }^{4}$. Ayak bileği artritine sıklıkla ayak bileği ödemi eşlik etmektedir. Eklem ultrasonografisinde tipik artrit bulgularından ziyade periartiküler yumuşak doku ödemi görülür ${ }^{6,2,7}$. Çalışmamızda da literatüre benzer şekilde hastaların çoğu (\%75) oligoartiküler ve simetrik (\%83) seyretmiştir. Ayak bileği artrit sıklığı da diğer çalışmalarda olduğu gibidir ve çalışmamızda hastaların tamamında ayak bileği artriti izlenmiş olup \%83,3'ünde bilateral ayak 
bileği artriti saptanmıştır. Yine literatüre benzer şekilde hastaların \%75'inde ayak bileği ödemi izlenmiştir. Çalışmamızda ayak bileğinden sonra en sık diz, el bileği, Mkf, Mtf, Pif, dirsek ve kalça eklemlerinde tutulum görülmüştür.

Aggarwal V. ve arkadaşlarının yaptığı ve 117 sarkoid artritinin dahil edildiği bir çalışmada omuz, el bileği, Mkf, Pif ve diz tutulumunun anlamlı olarak akut artrite göre kronik sarkoid artritinde daha sık olduğu gözlemlenmiştir ${ }^{5}$. Löfgren sendromu eklem bulguları sarkoidozun genel eklem bulguları ile paralel olabilir bu konunun aydınlatılması için Löfgren sendromlu ve kronik sarkoid artritli hastaların karşılaştırıldığı çalışmalara ihtiyaç vardır. Löfgren sendromunda bazen romatoid artiti taklit edebilen izole küçük eklem tutulumu görülebilir ${ }^{8,9}$. Nadiren sakroiliak eklem ve temporomandibuler eklem de etkilenebilir ${ }^{10}$. Çalışmamızda kronik artritli hasta grubunda Pif ve dirsek tutulumu olan hastalar olmasına rağmen, akut artritli grupta hiç Pif ve dirsek tutulumu gözlemlenmemiştir. El bileği tutulumu ise kronik artritli hastaların \%40'ında görülürken, akut artrit grubunun sadece \%14,2'sinde gözlenmiştir. İstatistiksel olarak anlamlı bulunmasa bile el bileği, dirsek ve Pif tutulumunun kronik hastalarda daha s1k görüldüğü ve kronikleşmeyi ön gördürebileceği bizim çalışmamızda da desteklenmektedir. Löfgren sendromu, sarkoidoz hastalarının \%5-10'unu oluşturur ve sıklıkla kendini sınırlar. Kronik artrit ise sarkoidoz hastalarının \%1-2'sini oluşturur. Hastaların yaklaşık üçte birinde kronik artrite dönüşebilir, nadiren tekrarlayıcı da olabilir ${ }^{8}$. Çalışmamızda hastaların \%58'i akut seyirli olup, \%42'si kronik seyretmiştir; kronik seyirli hasta sıklığı diğer çalışmalardan farklı olarak çalışmamızda daha fazla gözlenmiştir.

Löfgren sendromunda laboratuvar testleri tanı için gerekli ve spesifik değildir. Tetkiklerde lenfopeni, hiperkalsemi, Crp artışı, Ade'de yükselme, poliklonal hipergamaglobulinemi görülebilir. Bir çalışmada çok yüksek Ade düzeyleri kronik artritle ilişkilendirilmiştir $^{11-14}$. Fakat başka bir çalışmada Ade düzeylerinin akut ve kronik hastalarda farklı seyretmediği bildirilmiştir. Çalışmamızda da akut ve kronik seyirli hastalar arasında Ade düzeyleri açısından anlamlı bir fark saptanmamıştır ve diğer çalışmalardakinin aksine akut artritte daha yüksek olma eğiliminde olduğu görülmüştür.

Löfgren sendromu çoğunlukla 1-2 yıl içerisinde spontan geriler ve hastaların çoğunda 6 hafta içerisinde düzelme görülür ${ }^{1,15}$. Çalışmamızda da hastaların çoğunda (\%58) 6 hafta içerisinde düzelme görülmüş olup, akut seyirlilerde ortalama semptom düzelme süresi 3 hafta olarak belirlenmiștir. Löfgren sendromunda eklem tutulumu her ne kadar kendi kendini sınırlar özellikte olsa da vakaların 3 'te bir gibi azımsanmayacak bir bölümünde bulgular uzayabilir ve hastalığı modifiye eden ilaçlar tedavide (Dmard) kullanılabilir ${ }^{8}$. Literatürde kronik artritte prednizolon, kolşisin, Hk, Mt, Tnf inhibitörü gibi ilaçların kullanımından bahsedilmiş olsa da kullanılan ilaçlardan hangisinin kronikleşmeyi engellediğini araştıran bir klinik çalışma yoktur ${ }^{15-18}$. Çalışmamızda Ssz kullanan 5 hastanın 4'ünde semptomların 6 haftadan kısa sürdüğü, kolşisin kullanan 3 hastanın hepsinde, Hk kullanan 4 hastanın 3'ünde ise semptomların 6 haftadan daha uzun sürdüğü görüldü, bu nedenle Löfgren sendromunda Ssz'nin Hk ve kolşisine kıyasla eklem semptomlarını kontrol altına almada daha başarılı olabileceğini düşündürdü. Löfgren sendromu, alt ekstremite büyük eklem tutulumu nedeniyle reaktif artrit ile sıklıkla karışır. Reaktif artrit ön tanısı ile tetkik edilen 189 hastanın dahil edildiği prospektif bir çalışmada, 17 hasta (\%9) takiplerde akut sarkoid artriti tanis1 almıştır. Çalışmamızda 5 hastaya başvuru esnasında ayırıcı tanıda reaktif artrit de düşünülmesi nedeniyle Ssz tedavisi başlanmıştır. Hastaların takiplerinde sarkoidoz tanısı aldığı ve Ssz alan hastaların \%80'inin tedaviden fayda gördüğü, istatistiksel olarak anlamlı olmasa bile, Ssz'nin eklem bulgularını kontrol etmede ve kronikleşmeyi engellemede etkili bir Dmard olduğu düşünülmüştür. Literatürde Löfgren sendromunda eklem bulgularının tedavisinde ya da akut-kronik sarkoid artritin tedavisinde Ssz etkisini inceleyen bir çalışma bulunmamaktadır. Sadece Löfgren sendromu ve ankilozan spondilit birlikteliği olan bir vakada Ssz kullanımından bahsedilmiştir ${ }^{19}$. Bu nedenle çalışmamız Löfgren sendromunun eklem tutulumunda Ssz'nin de etkili olabileceğini göstermesi açısından önemlidir. Çalışmamızda kronik vakaların çoğunda Hk ve kolşisin kullanıldığı ve bu ilaçların kronikleşmeyi engellemede etkisinin olmayabileceği görülmüştür. Kolşisin romatolojide daha çok periodik ateş sendromu ve kristal artropatiler gibi otoinflamatuvar hastalıklardaki inflamasyonu kontrol etmede kullanılan bir ilaçtır. Bu nedenle otoimmün bir hastalık olan sarkoidozda inflamasyonun kontrol altına alınmasında yeterince etkili olamayabilir. Hk de potensi düşük bir anti inflamatuvar ilaç olduğu için Ssz ya da diğer Dmard'lar kadar etkili bir tedavi seçeneği olmayabilir. Mt etkili bir Dmard olarak kullanılabilecek bir ilaç olsa da çalışmamızda kullanan sadece 1 hasta olması sebebiyle kronikleşme üzerindeki etkisini değerlendirmek mümkün olmamıştır.

Çalışmamızın en önemli kısıtlılıklarından biri retrospektif bir çalışma olması nedeniyle hastaların ilaçlarını düzenli kullanıp kullanmadıklarını ve semptomların tam olarak kaç günde düzeldiğini değerlendirmenin objektif olmayabileceğidir. Vaka sayısının az olması sebebiyle tutulan eklem paterninin akut ve kronik artrit seyrindeki farklılıklarını ve verilen tedavilerin kronikleşmeyi engellemedeki etkilerini değerlendirmenin zor olması çalışmanın diğer önemli bir kısıtlıl1ğıdır. Aynı şekilde ilaçların bir hastalıktaki etkisinin değerlendirilebilmesi için örneklem büyüklüğünün yeterli olması en önemli unsurlardandır. Bu çalışmada örneklem büyüklüğünün ilaç etkisini değerlendirebil- 


\section{Löfgren Sendromunda Kas-iskelet Sistemi Bulguları}

mek için çok yetersiz olması da çalışmanın önemli eksikliklerindendir. Her ne kadar klinik olarak hiçbir hastada romatoid artrit düşünülmemiş olsa da bu çalışmada özellikle klinik olarak üst ekstremite artriti olan olguların romatoid artrit yönünden ayrıntılı bir değerlendirmeden geçirilmemiş olması çalışmanın eksikliklerindendir.

Biz bu çalışmada, sarkoidozun daha çok çift taraflı ayak bileği artritine eşlik eden ayak bileği ödemi ile seyrettiğini, semptomların kendi kendini sınırlama eğilimi olsa da semptomların uzayabileceğini, başlangıç laboratuvar bulgularının ve hastalığın eklem bulgularının süresini öngörebilecek herhangi ayırt edici laboratuvar veya klinik bulgusunun olmadığını, el bileği, Pif ve dirsek tutulumunun kronik artritte daha s1k tutulabileceğini, kolşisin veya $\mathrm{Hk}$ kullananlarda semptomların 6 haftadan uzun sürebileceğini ve Ssz'nin bu noktada daha hızlı yanıt için iyi bir tedavi seçeneği olabileceğini gösterdik. Ancak bulgularımızın doğruluğunun sorgulanması için daha geniş katılım ve prospektif çalışmalara ihtiyaç vardır.

Löfgren sendromunda el bileği, proksimal interfalangial eklem ve dirsek tutulumu kronik artrit seyrinde daha sıktır, anjiyotensin dönüştürücü enzim akut artritte daha yüksek görülme eğilimindedir; bunun dışında hastalığın seyrinde ayırt ettirici olabilecek karakteristik klinik ve laboratuvar özellik yoktur. Sülfasalazin gibi potensi yüksek hastalığı modifiye edici ilaçlar hastalığın eklem bulgularının daha kısa sürede kontrol altına alınmasında etkili olabilirler.

\section{Teşekkür}

Yazarlar olarak, Tufan Teker'e çalışma verilerinin toplanmasındaki yardımlarından ötürü teşekkür ederiz.

\section{Etik Kurul Onay Bilgisi:}

Onaylayan Kurul: Sağlık Bilimleri Üniversitesi Bursa Yüksek İhtisas Eğitim ve Araştırma Hastanesi Klinik Araştırmalar Etik Kurulu.

Onay Tarihi: 04.03.2020

Karar No: 2011-KAEK-25 2020/03-18

\section{Kaynaklar}

1. Ungprasert P, Crowson CS, Matteson EL. Clinical Characteristics of Sarcoid Arthropathy: A Population-Based Study. Arthritis Care Res (Hoboken) 2016; 68 (5):695-699. doi:10.1002/acr.22737.

2. Brown F, Modi P, Tanner LS. Lofgren Syndrome. In: StatPearls [Internet]. Treasure Island (FL): StatPearls Publishing; 2020 Jan. 2020 Aug 8.
3. O'Regan A, Berman JS.Sarcoidosis. Ann Intern Med 156 (9) 2012:ITC5-1, ITC5-2, ITC5-3, ITC5-4, ITC5-5, ITC5-6, ITC57, ITC5-8, ITC5-9, ITC5-10, ITC15-11, ITC15-12, ITC15-13, ITC15-14, ITC15-15; quiz ITC15-16. doi:10.7326/0003-4819156-9-201205010-01005.

4. Visser H, Vos K, Zanelli E, et al. Sarcoid arthritis: clinical characteristics, diagnostic aspects, and risk factors. Ann Rheum Dis.2002;61 (6):499-504. doi:10.1136/ard.61.6.499.

5. Arthritis in Sarcoidosis G, Agarwal V, Agrawal V, Aggarwal A, Aggarwal P, et al. Arthritis in sarcoidosis: A multicentric study from India. Int J Rheum Dis. 2018;21 (9):1728-1733. doi:10.1111/1756-185X.13349.

6. Kobak S. Sarcoidosis: a rheumatologist's perspective. Ther Adv Musculoskelet Dis 2015;7 (5):196-205. doi: 10.1177/1759720X15591310.

7. Mana J, Gomez-Vaquero C, Montero A, Salazar A, et al. Lofgren's syndrome revisited: a study of 186 patients. Am J Med 1999;107 (3):240-245. doi:10.1016/s0002-9343(99)00223-5.

8. Johard U, Eklund A. Recurrent Lofgren's syndrome in three patients with sarcoidosis. Sarcoidosis1993;10 (2):125-127.

9. Kaufman LD. Lofgren's syndrome (acute sarcoidosis) sine erythema nodosum mimicking acute rheumatoid arthritis. N Y State J Med 1990;90 (9):463-464.

10. Griep EN, van Spiegel PI, van Soesbergen RM. Sarcoidosis accompanied by pulmonary tuberculosis and complicated by sacroiliitis. Arthritis Rheum 1993;36 (5):716-721. doi:10.1002/art.1780360521.

11. Sequeira W, Stinar D. Serum angiotensin-converting enzyme levels in sarcoid arthritis. Arch Intern Med 1986;146 (1):125127.

12. Sejdic A, Graudal N, Baslund B. Clinical and biochemical presentation of sarcoidosis with high and normal serum angiotensin-converting enzyme. Scand J Rheumatol 2018;47 (6):487490. doi:10.1080/03009742.2017.1420818.

13. Romer FK. Clinical and biochemical aspects of sarcoidosis. With special reference to angiotensin-converting enzyme. Acta Med Scand Suppl 1984;690:3-96.

14. Muthuswamy PP, Lopez-Majano V, Ranginwala M, Trainor WD. Serum angiotensin-converting enzyme activity as an indicator of total body granuloma load and prognosis in sarcoidosis. Sarcoidosis 1984;4 (2):142-148.

15. Zisman DA, Shorr AF, Lynch JP, 3rd. Sarcoidosis involving the musculoskeletal system. Semin Respir Crit Care Med 2002;23 (6):555-570. doi:10.1055/s-2002-36520.

16. Baughman RP, Lower EE. Steroid-sparing alternative treatments for sarcoidosis. Clin Chest Med 1997;18 (4):853-864. doi:10.1016/s0272-5231(05)70423-8.

17. Kaye O, Palazzo E, Grossin M, Bourgeois P, Kahn MF, Malaise MG. Low-dose methotrexate: an effective corticosteroidsparing agent in the musculoskeletal manifestations of sarcoi$\begin{array}{lllll}\text { dosis. } & \mathrm{Br} & \mathrm{J} & \text { Rheumatol 1995;34 (7):642-644. }\end{array}$ doi:10.1093/rheumatology/34.7.642.

18. Sweiss NJ, Welsch MJ, Curran JJ, Ellman MH. (2005) Tumor necrosis factor inhibition as a novel treatment for refractory sarcoidosis. Arthritis Rheum2005;53 (5):788-791. doi:10.1002/art.21468.

19. Kobak S, Sever F, Ince O, Orman M. The prevalence of sacroiliitis and spondyloarthritis in patients with sarcoidosis. Int $\mathrm{J}$ Rheumatol 2014:289454. doi:10.1155/2014/289454. 
